\title{
Australian Journal of \\ Crop Science \\ Greenhouse gas emission from the soils fertilized with liquid pig slurry (LPS) in Tifton 85 bermudagrass pasture in tropical savanna
}

\author{
Adilson Amorim Brandão ${ }^{1 *}$, Eduardo Guimarães Couto ${ }^{2}$, Renato de Aragão Ribeiro Rodrigues ${ }^{3}$, Oscarlina \\ Lúcia Santos Weber ${ }^{2}$, Osvaldo Borges Pinto Júnior ${ }^{4}$
}

\author{
${ }^{1}$ Federal Institute of Mato Grosso do Sul, Naviraí, 79950-000, Mato Grosso do Sul, Brazil \\ ${ }^{2}$ Federal University of Mato Grosso, Department of Soils and Rural Engineering, Cuiabá, 78060-900, Mato \\ Grosso, Brazil \\ ${ }^{3}$ Embrapa Soils, Rio de Janeiro, 22460-000, Rio de Janeiro, Brazil \\ ${ }^{4}$ University of Cuiabá, Cuiabá, 78065-900, Mato Grosso, Brazil
}

\section{*Corresponding author: aabrandaojr@gmail.com}

\section{Abstract}

Soils have important roles in the global budgets of the greenhouse gases. The liquid pig slurry (LPS) in pastures has high potential as a fertilizer but could have a direct influence on emission of greenhouse gasses. This study evaluated the effects of the application of LPS and inorganic mineral fertilization during the rainy and dry seasons on the emissions of $\mathrm{CO}_{2}, \mathrm{CH}_{4}$ and $\mathrm{N}_{2} \mathrm{O}$ in pastures planted with Tifton-85. The following treatments were tested: Control - no fertilization; LPS30 - $30 \mathrm{~m}^{3} \mathrm{ha}^{-1}$; LPS60 - $60 \mathrm{~m}^{3} \mathrm{ha}^{-1} ;$ LPS90 - $90 \mathrm{~m}^{3}$ $\mathrm{ha}^{-1}$ and inorganic mineral fertilization. Gasses were sampled using static chambers first during the months of March and April, then in June and July. Fertilization with LPS caused an increase in the flux of $\mathrm{CO}_{2}$ and $\mathrm{CH}_{4}$ during the first hours after its application, and $\mathrm{CO}_{2}$ emissions are greater during the rainy than in the dry season. However, the application of LPS in Tifton- 85 pasture during rainy periods did not show high potential for emission of $\mathrm{CO}_{2}$, in contrast to application during the dry season. Fertilization with LPS increases the emission of $\mathrm{N}_{2} \mathrm{O}$, and this varies as a function of the volume of LPS applied and the experimental conditions experimental conditions. The application of LPS in Tifton-85 pasture has a high potential for $\mathrm{N}_{2} \mathrm{O}$ emission during the rainy season, but the magnitude is similar to that resulting from inorganic mineral fertilization.

Keywords: swine wastewater, soil gas fluxes, carbon dioxide, methane, nitrous oxide.

Abbreviations: LPS_liquid pig slurry; DAA_day after application; GHG_greenhouse gas; IC intensive collection.

\section{Introduction}

The expansion of pasture for livestock production is the main responsible for land use change (LUC) emissions contributing for $6 \%$ of global emissions from livestock. The LUC emission from soybean is also a substantial driver of LUC emissions, covering $3.2 \%$ of global emissions from livestock (Gerber et al., 2013). The gas emission in Brazil is mostly caused by cattle, expansion of pasture for production of feed ingredients such as soybean (Karstensen et al., 2013) for pigs and poultry. In fact, pigs and poultry are mostly fed ingredients containing grain and soy products (Kebreab et al.,2016). Brazilian production of pork is increasing, with a $28.2 \%$ growth rate expected by the end of 2029 (MAPA, 2019). However, a consequence of pig farming is the generation and concentration of a large volume of excrement, which represents an environmental risk and requires measures to be taken to reduce negative impacts on the surrounding environment (Ceretta et al., 2005).

Pork farming in a confined system generates concentrated liquid slurry in specific areas on rural properties (Damasceno, 2010). For example, in the state of Mato Grosso, the estimated annual production of slurry in 2018 by pig herd amounted 2.94 million, according IBGE (2018). I corresponds to a daily production of 7 liters of liquid slurry per animal (Oliveira, 2004), by which the annual slurry production is approximately 7.51 million $\mathrm{m}^{3}$.

The application of liquid pig slurry (LPS) in pastures is a viable alternative for its use because as a function of its chemical characteristics it has great potential to be used as a fertilizer (Seidel et al., 2010). Therefore, LPS could partially or totally substitute inorganic mineral fertilizer and make a significant contribution to crop production and reduce input costs (Scherer et al., 2012). The most common form of use of LPS is in application to the surface of agricultural soils due to its lower operational costs and ease of application in most cultivation systems (Friederichs et al., 2019), and also because it favors the accumulation of nutrients in the root zone of agricultural soils (Veiga et al., 2012; Friederichs, 2019). However, the inadequate use of LPS can increase the risk of microbiological contamination of groundwater, accumulation of toxic elements, nutrient imbalances and soil impermeabilization (Seganfredo, 2000), besides having a direct influence on the emissions of carbon dioxide $\left(\mathrm{CO}_{2}\right)$, 
methane $\left(\mathrm{CH}_{4}\right)$ and nitrous oxide $\left(\mathrm{N}_{2} \mathrm{O}\right)$, and on volatilization of ammonia $\left(\mathrm{NH}_{3}\right)$ (Carvalho and Hentz, 2014).

The emission of $\mathrm{CO}_{2}$ from the soil occurs as a function of respiration of roots and organisms together with decomposition of organic residuals (Carvalho et al,, 2010). These processes are influenced by the application of LPS to the soil due to an increase in organic carbon, and consequently an increase in microbial respiration and activity (Webb et al., 2010). Furthermore, fertilization with LPS contributes to the development of agricultural crops by increasing plant root systems and the input of plant residual materials to the soil.

In research conducted in a controlled laboratory environment, $\mathrm{CO}_{2}$ flux was $125 \mathrm{mg} \mathrm{C} \mathrm{m}^{-2} \mathrm{~h}^{-1}$ one day after application (DAA) of LPS (200 kg N ha ${ }^{-1}$ ) in an uncultivated clay soil, while in a soil without application of LPS the flux was $40 \mathrm{mg} \mathrm{C} \mathrm{m}^{-2} \mathrm{~h}^{-1}$ (Jarecki et al., 2008). In a no-till soil cultivated with a wheat and corn rotation of $\mathrm{CO}_{2}$ flux rates varied between 60 and $208 \mathrm{mg} \mathrm{m}^{-2} \mathrm{~h}^{-1}$ and after treatment of LPS at rate of $140 \mathrm{~kg} \mathrm{~N} \mathrm{ha}^{-1}$. These rates remained higher than those of the control treatment during the first 18 days after application (Grave et al., 2015).

The flux of soil $\mathrm{CH}_{4}$ is the result of production of this gas in the soil by methanogenic bacteria under anaerobic conditions, and also the oxidation that occurs through the action of methanotrophic bacteria in the presence of oxygen (Le Mer and Roger, 2001). The oxidation of methane is generally greater than its production in well-drained and aerated soils. However, the application of different forms of nitrogen can considerably reduce the rates of oxidation of $\mathrm{CH}_{4}$ (Suwanwaree and Robertson, 2005).

In a study conducted in New Zealand, $\mathrm{CH}_{4}$ flux was measured during 90 days after the application of $60 \mathrm{~m}^{3} \mathrm{ha}^{-1}$ of LPS to a pasture. The flux of soil $\mathrm{CH}_{4}$ was $3,933 \mu \mathrm{g} \mathrm{C} \mathrm{m} \mathrm{h}^{-2} \mathrm{~h}^{-1}$ immediately after application of LPS and continued at a lower rate until the $7^{\text {th }}$ DAA. From the $8^{\text {th }}$ DAA onward the measured fluxes indicated absorption of atmospheric methane by the soil (Sherlock et al., 2002).

In Frederico Westphalen-RS, Brazil, treatments applying LPS were evaluated with the objective of measuring greenhouse gas emissions as a function of the method of application to no-till soil cultivated with a wheat and corn rotation (Arenhardt, 2016). The results showed that the accumulated $\mathrm{CH}_{4}$ emissions from soil where LPS was applied on the surface were negative, meaning that methane was absorbed, although there was soil $\mathrm{CH}_{4}$ efflux soon after LPS application.

The volatilization of ammonia $\left(\mathrm{NH}_{3}\right)$ is considered to be the principal mechanism of loss of nitrogen $(\mathrm{N})$ after application of liquid residuals to the soil (Smith et al., 2009). This reduces the potential of nitrogen as a fertilizer and contributes to environmental contamination (Rochette et al., 2008). Losses of ammonia are generally high and can reach $75 \%$ of $\mathrm{NH}_{4}^{+}-\mathrm{N}$ when liquid residuals, principally those from pigs, are applied with incorporation into the soil (Thompson and Meisinger, 2002). Although ammonia is not a greenhouse gas (GHG) itself, but its emission to the atmosphere and subsequent deposition on the soil can result in production of nitrous oxide $\left(\mathrm{N}_{2} \mathrm{O}\right)$ as a by-product of the microbial nitrification process, and also as a product of microbial denitrification (Zaman and Blennerhassett, 2010). The Inter-governmental Panel on Climate Change (IPCC) estimates that, on average, $1.25 \%$ of total $\mathrm{N}$ from fertilizer or manure applied to soil is emitted as $\mathrm{N}_{2} \mathrm{O}$ (IPCC, 2007).
In a study conducted in the Brazilian state of Rio Grande do Sul, the flux of soil $\mathrm{N}_{2} \mathrm{O}$ in a no-till system using an oat mulch was increased by $160 \mu \mathrm{g} \mathrm{N} \mathrm{m} \mathrm{h}^{-2}$ four hours after the application of $40 \mathrm{~m}^{-3} \mathrm{ha}^{-1}$, compared to the treatment without LPS. The accumulated emission of $\mathrm{N}_{2} \mathrm{O} 28$ days after application was $93.8 \mathrm{~g} \mathrm{~N} \mathrm{ha}^{-1}$ (Giacomini et al., 2006). This dynamic of more intense $\mathrm{N}_{2} \mathrm{O}$ flux during the first DAA after LPS application has been reported in the literature for temperate climate conditions (Rochette et al., 2008; Pelster et al., 2012) as well as for subtropical (Aita et al., 2014, Aita et al., 2015).

The potential of LPS for the use as a substitute for inorganic mineral fertilization in agricultural production, including for forage grasses in pasture systems, is widely reported in the literature (Drumond et al., 2006; Medeiros et al., 2007; Camargo et al., 2011; Silva et al., 2015). However, it is necessary to evaluate the dimensions of the impacts of LPS application with respect to the emissions of $\mathrm{CO}_{2}, \mathrm{CH}_{4}$ and $\mathrm{N}_{2} \mathrm{O}$ in pasture areas, especially in regions with a tropical climate. These GHG are important for atmospheric chemistry and its radiation balance as a function of their lifetimes in the atmosphere, and also because of the values for relative global warming potential (GWP) of $\mathrm{CH}_{4}$ and $\mathrm{N}_{2} \mathrm{O}$ which are respectively about 25 and 298 times greater than that of $\mathrm{CO}_{2}$ (IPCC, 2007).

The objective of this study was to evaluate the effects of the application of LPS and inorganic mineral fertilization during the rainy and dry seasons on the emissions of $\mathrm{CO}_{2}, \mathrm{CH}_{4}$ and $\mathrm{N}_{2} \mathrm{O}$ in pastures planted with Tifton-85.

\section{Results and Discussion}

\section{Daily average flux of $\mathrm{CO}_{2}, \mathrm{CH}_{4}$ and $\mathrm{N}_{2} \mathrm{O}$ during the intensive collection campaigns}

Before application of fertilizer two intensive collection (IC) campaigns were conducted. The $\mathrm{CO}_{2}$ fluxes were similar between the two treatments. Starting on the first day after fertilizer application (DAA), in the first IC as well as for the second IC the flux was increased in the treatments LPS30, LPS60 and LPS90 (Figs $1 \mathrm{~A}$ and 1B). In the first IC, treatment LPS90 had a $\mathrm{CO}_{2}$ flux above $500 \mathrm{mg} \mathrm{m}^{-2} \mathrm{~h}^{-1}$ and was statistically different from the other treatments $\left(F_{4 ; 12}=3.506\right.$; $\mathrm{p}<0.05)$. In the second IC, treatments LPS30, LPS60 and LPS90 had similar $\mathrm{CO}_{2}$ flux values, but differed from those for the Control and FertMin treatments $\left(F_{4 ; 12}=4.941 ; p<0.05\right)$. In general, the greater the rate of application of LPS, the higher the emission values for $\mathrm{CO}_{2}$ on the $1^{\text {st }}$ DAA. The $\mathrm{CO}_{2}$ flux was decreased starting from $2^{\text {nd }}$ DAA until the end of the evaluation period for both the first and second ICs, with no differences between treatments.

The application of LPS to the soil stimulates an increase in $\mathrm{CO}_{2}$ emission during the first hours after application, with about $59 \%$ of the organic carbon added in LPS being emitted as $\mathrm{CO}_{2}$, independent of the application method to the soil (Giacomini et al., 2007). The increase in $\mathrm{CO}_{2}$ emission during the first hours after LPS application is reported in the literature (Aita, Port and Giacomini, 2006; Giacomini et al., 2007; Giacomini and Aita, 2008; Arenhardt, 2016) and could be linked to the liberation of $\mathrm{CO}_{2}$ dissolved in the LPS, as well as $\mathrm{CO}_{2}$ formed from $\mathrm{HCO}_{3}^{-}$and $\mathrm{CO}_{3}{ }^{2-}$ generated during storage of this material (Carvalho and Hentz, 2014). Evidence for this shown by the fact that the $\mathrm{CO}_{2}$ flux values on the days preceding the application of the LPS to the soil 
varied between 1 and $2 \mathrm{~kg} \mathrm{ha}^{-1} \mathrm{~h}^{-1}$ independent of the treatment.

During the $1^{\text {st }} \mathrm{IC}$, several rainfall events apparently influenced the $\mathrm{CO}_{2}$ flux in all treatments, with peaks of $\mathrm{C}-\mathrm{CO}_{2}$ flux on March 27 and 29, and April 1 (Fig 1A). This effect is due to the fact that precipitation increases soil biological activity, and this is reflected in greater respiration and $\mathrm{CO}_{2}$ emission rates (Luo and Zhou, 2006a, 2006b).

The fluxes of $\mathrm{CH}_{4}$ were equal before the application of the treatments for each IC, showing emission peaks after the application of the LPS. From the $7^{\text {th }}$ DAA, the fluxes diminished and became similar between treatments (Figs $1 C$ and $1 D)$. In the $1^{\text {st }}$ IC there were differences between treatments only on day 1 and from the $5^{\text {th }}$ to the $7^{\text {th }}$ DAA (Fig 1C). On the $1^{\text {st }}$ DAA, treatment LPS90 had an emission of $642.7 \mu \mathrm{g} \mathrm{m}^{-2} \mathrm{~h}^{-1}$ and was different from the other treatments $\left(\mathrm{F}_{4 ; 12}=6.869 ; \mathrm{p}<0.05\right)$. The FertMin treatment had a $\mathrm{C}-\mathrm{CH}_{4}$ flux of $-7,4 \mu \mathrm{g} \mathrm{m}^{-2} \mathrm{~h}^{-1}$ on the $5^{\text {th }}$ DAA and was different from the other treatments $\left(\mathrm{F}_{4 ; 12}=6.533 ; \mathrm{p}<0.01\right)$, which all showed a positive flux for methane. On the $6^{\text {th }}$ and 7 th DAA, the treatment LPS30 had higher values than the other treatments, with a flux of $20.1 \mu \mathrm{g} \mathrm{m}^{-2} \mathrm{~h}^{-1}$ and $38.0 \mu \mathrm{g} \mathrm{m}^{-2} \mathrm{~h}^{-1}$, respectively.

The flux values for $\mathrm{CH}_{4}$ during the $2^{\text {nd }} \mathrm{IC}$ was increased in the treatments with LPS a few hours after its application (Fig $1 D)$, as also shown for the $1^{\text {st }}$ IC. On the 1 st DAA, $\mathrm{CH}_{4}$ emissions for LPS60 and LPS90 were 45.7 and $47.0 \mu \mathrm{g} \mathrm{m}^{-2} \mathrm{~h}^{-1}$, respectively, and were different from the other treatments $\left(F_{4 ; 12}=4.028 ; p<0.05\right)$. Treatments LPS90 and FertMin had similar or greater values than those from the other treatments on the $5^{\text {th }}$ DAA $\left(F_{4 ; 12}=5.178 ; p<0.05\right)$.

The emission peaks of methane are most likely related to volatilization of dissolved $\mathrm{CH}_{4}$ soon after application of LPS (Sherlock et al., 2002). Damasceno (2010) reported results that showed that methane emission is increases in the soil with addition of residuals from pork farming, with a methane emission rate of $600 \mu \mathrm{g} \mathrm{m}^{-2} \mathrm{~h}^{-1}$ soon after application of LPS on the soil surface. However, in the current study the increase in $\mathrm{CH}_{4}$ flux between the $5^{\text {th }}$ and $7^{\text {th }}$ DAA during the $1^{\text {st }}$ IC could be related to rainfall events that saturated the soil pores and formed anaerobic microenvironments that are favorable for methanogenesis.

In each IC, the majority of treatments showed negative values for $\mathrm{CH}_{4}$ flux (influx or absorption), indicating consumption of methane. This corroborated with Piva et al. (2013) in cultivated pasture on an Oxisol in Paraná. An influx of methane is expected for an aerated and well-structured soil such as the one in the current study because this soil type is considered to be a methane sink (Saggar et al., 2008). Before the fertilizer application, $\mathrm{N}_{2} \mathrm{O}$ fluxes were similar between the treatments in both ICs (Figs $1 \mathrm{E}$ and 1F). After the application of the LPS, from the $1^{\text {st }}$ to the $3^{\text {rd }}$ DAA, treatment LPS90 had greater emissions than the other treatments (Fig 1E). Between the $4^{\text {th }}$ and the $6^{\text {th }}$ DAA, an N$\mathrm{N} 2 \mathrm{O}$ emission in the inorganic mineral fertilization treatment was increased, which were similar to emissions from LPS90 on the 5th DAA and greater than those from the other treatments between the $4^{\text {th }}$ and the $6^{\text {th }}$ DAA. Starting on the $7^{\text {th }}$ DAA, average flux of $\mathrm{N}_{2} \mathrm{O}$ was lower and there was a difference between treatments only between the $7^{\text {th }}$ and $9^{\text {th }}$ DAA, with greater flux in LPS90 and FertMin (Fig 1E).

In the $2^{\text {nd }} I C$, there were differences between treatments only for the $1^{\text {st }}$ DAA (Fig 1F), with LPS60 and LPS90 having $\mathrm{N}_{2} \mathrm{O}$ fluxes greater than the other treatments. In general, during this period, the emission of $\mathrm{N}_{2} \mathrm{O}$ in the LPS treatments was greater.

The average $\mathrm{N}_{2} \mathrm{O}$ flux values in this study were lower than those reported by Denega (2009) principally after application of LPS, where this author observed emissions above $600 \mu \mathrm{g} \mathrm{m}^{-2} \mathrm{~h}^{-1}$ up to 48 hours after LPS application on soil covered with a corn mulch. However, the results from the current study are within the range reported in the literature (Giacomini et al., 2006).

The increase in $\mathrm{N}_{2} \mathrm{O}$ emission soon after LPS application to the soil has been reported in a large range of studies (Giacomini et al., 2006; Rochette et al., 2008; Denega, 2009; Arenhardt, 2016). The increase in $\mathrm{N}_{2} \mathrm{O}$ flux due to LPS application shown during the first two periods in the current study could be attributed to three factors: 1 ) the organic carbon in the LPS is used by aerobic microorganisms in the soil as a carbon and energy source. This increases their activity and demand for $\mathrm{O}_{2}$, which could create anaerobic sites. Certain types of microbes can respire using nitrate present in the soil as the final electron receptor in the respiratory chain reducing it to $\mathrm{N}_{2} \mathrm{O} 2$ ) the rapid nitrification of $\mathrm{NH}_{3}-\mathrm{N}$ applied with the LPS could result in the production of $\mathrm{N}_{2} \mathrm{O}$ by certain bacteria that possess the nitrite reductase enzyme 3 ) the liquid fraction could facilitate the occurrence of environments that are deficient in $\mathrm{O}_{2}$ depending on soil humidity and on the dose of LPS added to the soil, where nitrate could be denitrified and emitted to the atmosphere in the form of $\mathrm{N}_{2} \mathrm{O}$ (Giacomini et al., 2006).

The increase in the average daily fluxes in the treatment FertMin was observed in the $1^{\text {st }} \mathrm{IC}$ is in agreement with the literature (Aita et al., 2015; Arenhardt, 2016). The presence of mineral $\mathrm{N}$ combined with the humid soil creates a favorable environment for the denitrification process (Zanatta et al., 2010), which could explain the increase in the $\mathrm{N}_{2} \mathrm{O}$ flux observed in this study.

The lower emissions in the $2^{\text {nd }}$ IC compared to the $1^{\text {st }}$ IC could be related to low soil humidity during June 22 to July 5. The elevated capacity for water infiltration into the soil may favor the greater concentration of $\mathrm{O}_{2}$ in the soil profile, which represents and unfavorable situation for the denitrification process and consequently emission of $\mathrm{N}_{2} \mathrm{O}$ (Jantalia et al., 2008).

\section{Accumulated emission of $\mathrm{CO}_{2}, \mathrm{CH}_{4}$ and $\mathrm{N}_{2} \mathrm{O}$ during the intensive collection campaigns}

In the $1^{\text {st }} \mathrm{IC}$, the accumulated emissions of $\mathrm{CO}_{2}$ did not show any differences between the treatments (Fig $2 \mathrm{~A}$ ), indicating that during a period with more rainfall the application of LPS does not cause a significant increase in the flux of $\mathrm{CO}_{2}$. This could be explained by conditions that favor mineralization of carbon present in the soil including good levels of soil humidity and higher temperatures. However, during the $2^{\text {nd }}$ IC, the application of LPS resulted in an increase in accumulated emission, with emissions from LPS90 being 3fold greater compared to those of the Control (Fig 2A). Although the values of the accumulated emissions of $\mathrm{CO}_{2}$ of the $2^{\text {nd }}$ IC were inferior to those of the $1^{\text {st }}$ IC, the use of LPS for fertilization has high potential emissions of this gas during periods with lower rainfall.

The accumulated emissions of $\mathrm{CH}_{4}$ in the LPS treatments were greater in each IC (Fig 2B). During the $1^{\text {st }} \mathrm{IC}$, LPS90 had greater accumulated emission of methane than the other treatments, and together with LPS30 and LPS60 were the 
Table 1. Chemical composition of liquid pig slurry for each application date.

\begin{tabular}{|c|c|c|c|c|c|c|c|c|c|c|}
\hline \multirow{2}{*}{ Month/year } & $\mathrm{N}$ & $\mathrm{P}$ & $\mathrm{K}$ & $\mathrm{Ca}$ & $\mathrm{Mg}$ & \multirow[t]{2}{*}{$S$} & $\mathrm{Zn}$ & $\mathrm{Cu}$ & \multirow{2}{*}{$\mathrm{Mn}$} & \multirow[t]{2}{*}{$\mathrm{Fe}$} \\
\hline & \multicolumn{5}{|c|}{ 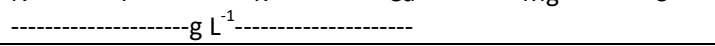 } & & \multirow{2}{*}{\multicolumn{4}{|c|}{$120 \quad 210$}} \\
\hline March/2015 & 2.10 & 0.70 & 0.40 & 0.15 & 0.09 & 0.41 & & & & \\
\hline June/2015 & 1.10 & 0.07 & 0.73 & 0.18 & 0.16 & 0.02 & 1.80 & 1.20 & 0.40 & 3.60 \\
\hline
\end{tabular}

$\mathrm{N}=$ nitrogen; $\mathrm{P}=$ phosphorus; $\mathrm{K}=$ potassium; $\mathrm{Ca}=$ calcium; $\mathrm{Mg}=$ magnesium; $\mathrm{S}=$ sulfur; $\mathrm{Zn}=$ zinc; $\mathrm{Cu}=$ copper; $\mathrm{Mn}=$ manganes; and Fe=iron.

A)

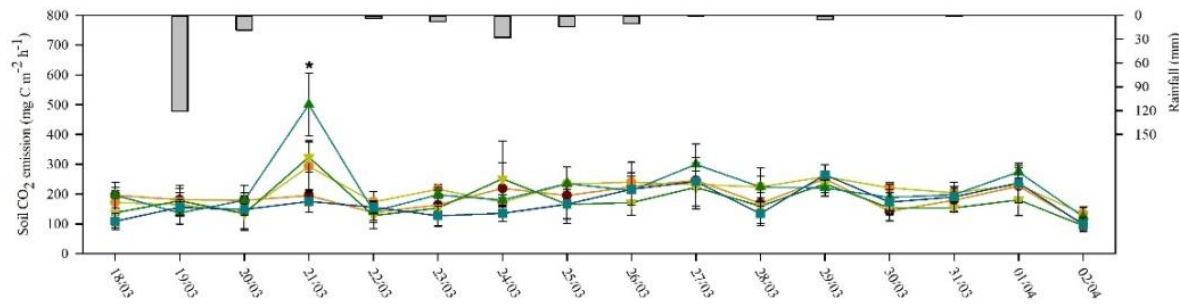

B)

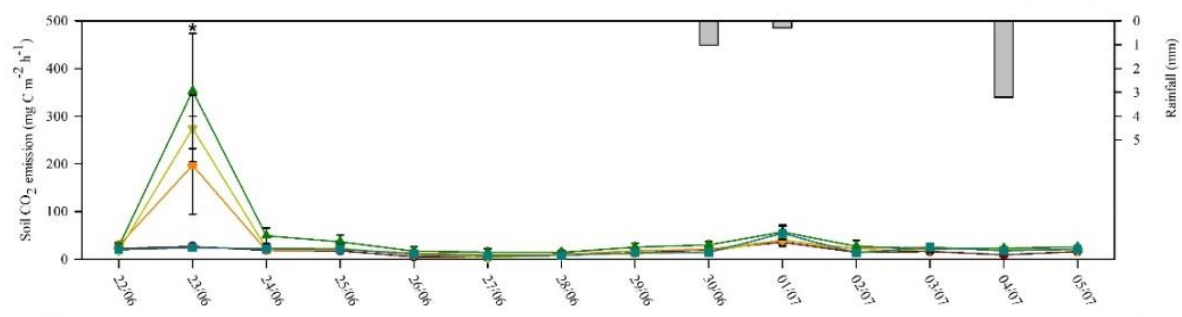

C)

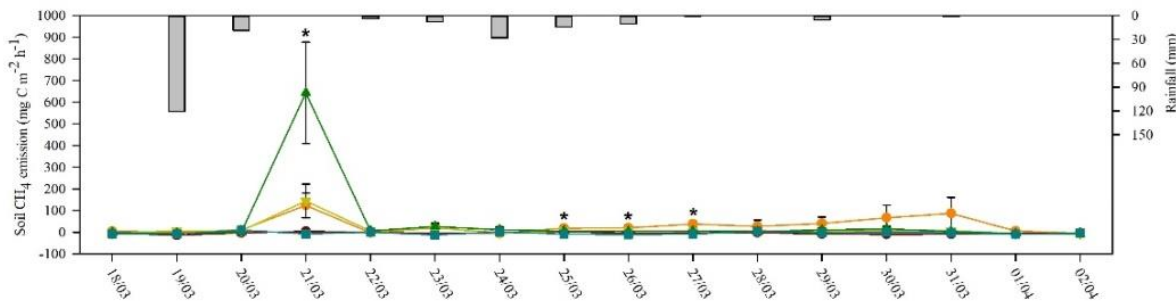

D)

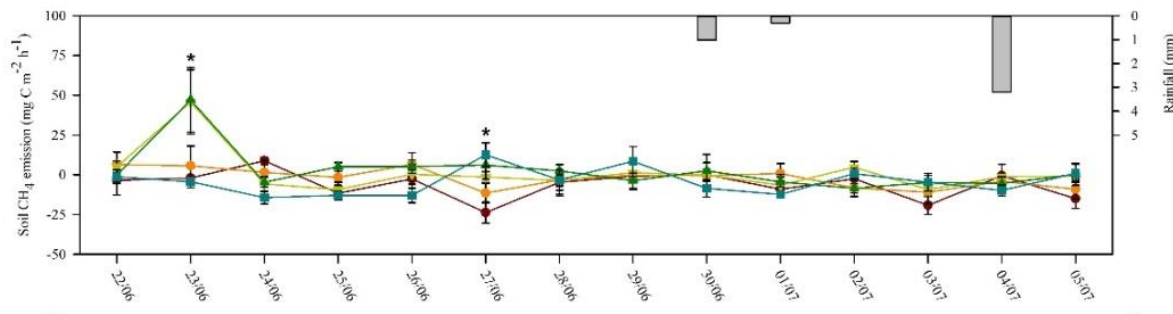

E)

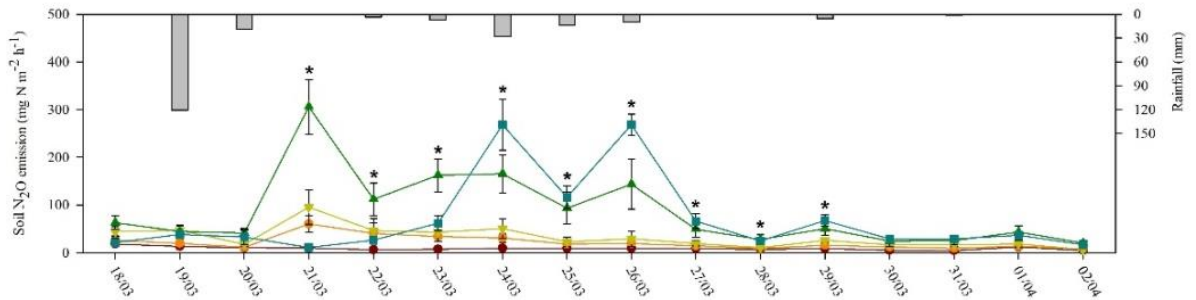

F)

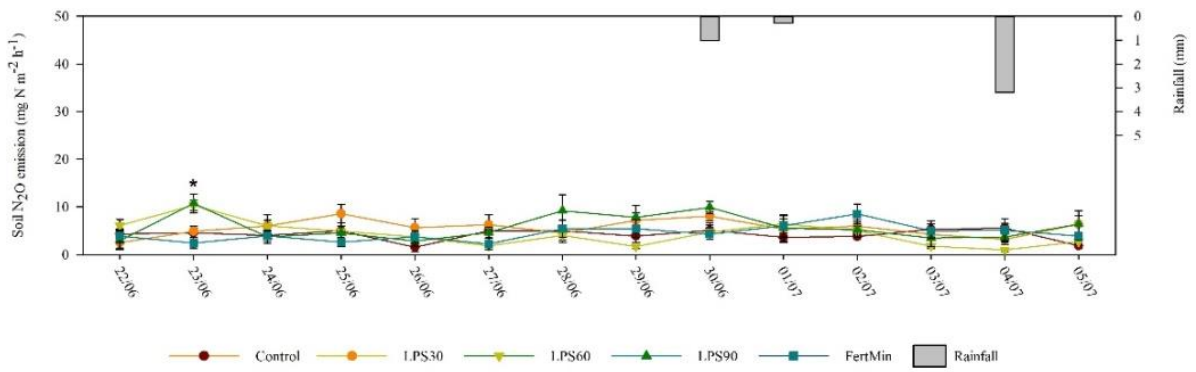

Fig 1. Average daily flux for $\mathrm{CO}_{2}$ in the $1^{\text {st }} \mathrm{IC}(\mathrm{A})$ and the $2^{\text {nd }} \mathrm{IC}(\mathrm{B}) ; \mathrm{CH}_{4}$ in the $1^{\text {st }} \mathrm{IC}(\mathrm{C})$ and the $2^{\text {nd }} \mathrm{IC}(\mathrm{D})$; and $\mathrm{N}_{2} \mathrm{O}$ in the $1^{\text {st }} \mathrm{IC}(\mathrm{E})$ and the $2^{\text {nd }}$ IC (F). Vertical bars represent the standard error of the mean $(n=4)$. *significant difference by the Tukey's test $(p<0.05)$. 

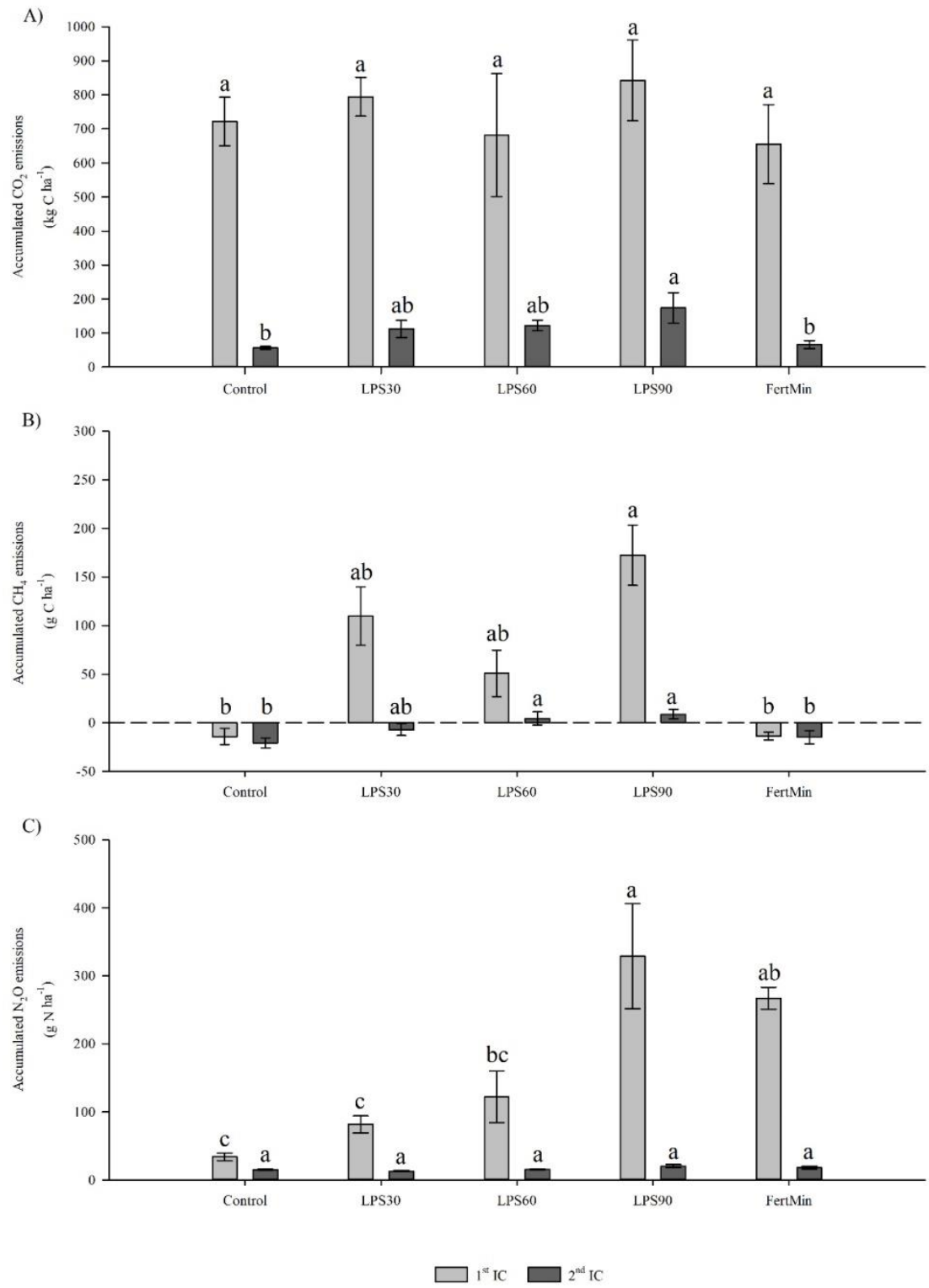

Fig 2. Accumulated emission of: (a) $\mathrm{CO}_{2}$, (b) $\mathrm{CH}_{4}$ and (c) $\mathrm{N}_{2} \mathrm{O}$ in the $1^{\text {st }}$ and $2^{\text {nd }}$ IC. The vertical bars represent the standard error of the mean $(n=4)$. Means followed by the same lowercase letters in to each intensive collection campaign does not differ statistically by the Tukey's test $(p<0.05)$.

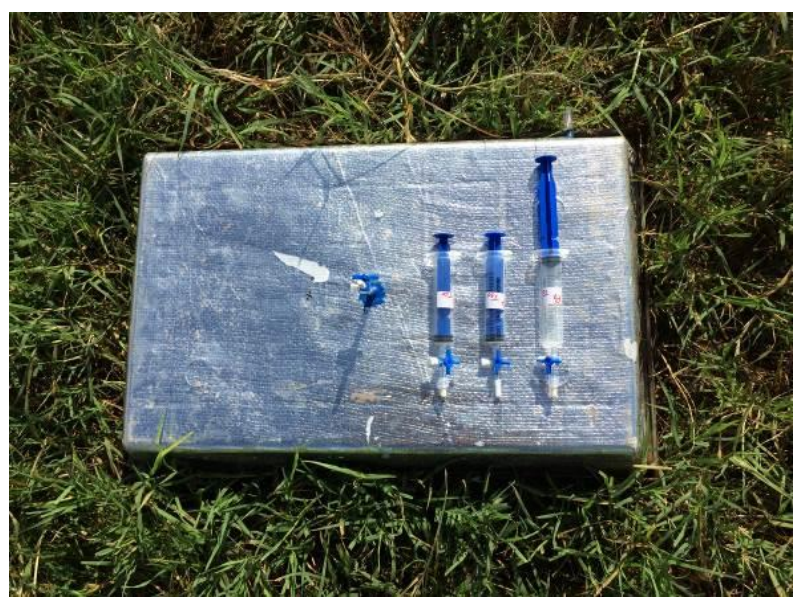

Fig 3. PVC chamber covered with a thermal insulation layer and three gas samplers (syringes) used for each collection period. 
sources of this gas. In the $2^{\text {nd }} I C$, LPS60 and LPS90 had greater accumulated emissions of $\mathrm{CH}_{4}$ and was a source of this gas to the atmosphere. In each of the intensive collection periods, the Control and FertMin treatments had negative accumulated emissions (influx), which characterized them as sinks of methane during the evaluation period (Fig 2B).

The accumulated emission of $\mathrm{N}_{2} \mathrm{O}$ during the $1^{\text {st }}$ IC showed a significant difference between treatments, with LPS90 and FertMin having greater emissions than the other treatments (Fig 2C). Greater accumulated emissions in the treatments with LPS and inorganic mineral fertilizer, but with no statistical differences, were reported by other studies (Arenhardt, 2016). In the $2^{\text {nd }} I C$, the accumulated emissions of $\mathrm{N}_{2} \mathrm{O}$ did not differ between treatments (Fig 2C). This fact could be associated with losses of $\mathrm{N}$ through volatilization of $\mathrm{NH}_{3}$ when LPS was applied to the soil surface, together with low soil humidity and a high level of oxygenation, which could have limited denitrification during this evaluation period (Aita et al., 2014).

\section{Materials and Methods}

\section{Study area and description of experiment}

The experiment was conducted under field conditions in the experimental area of the Rio Verde Foundation for Research and Technological Development, located at $13^{\circ} 00^{\prime} 02^{\prime \prime} \mathrm{S}, 55^{\circ}$ $58^{\prime} 15^{\prime \prime} \mathrm{W}$ and at an altitude of $387 \mathrm{~m}$, in the municipality of Lucas do Rio Verde - MT, on a Red-Yellow dystrophic Oxisol of clay texture. The chemical analysis of the soil from 0 to $0.20 \mathrm{~m}$ layer presented $\mathrm{pH}=4.53\left(\mathrm{H}_{2} \mathrm{O}\right) ; 14.22 \mathrm{mg} \mathrm{dm}^{-3} \mathrm{P}$; $106.28 \mathrm{mg} \mathrm{dm}^{-3} \mathrm{~K} ; 2.27 \mathrm{cmolc} \mathrm{dm}^{-3} \mathrm{Ca} ; 0.93 \mathrm{cmolc} \mathrm{dm}^{-3} \mathrm{Mg}$; $15.15 \mathrm{cmolc} \mathrm{dm}^{-3} \mathrm{H}+\mathrm{Al} ; 0.38 \mathrm{cmolc} \mathrm{dm}^{-3} \mathrm{Al}$ and $17.94 \%$ base saturation (V\%). The climate is Aw and tropical with dry winter season according to the Köppen classification system. The experimental design was randomized blocks with five treatments and four repetitions, for a total of 20 plots with an area of $55 \mathrm{~m}^{2}$ each, cultivated since March 2014 with a Tifton 85 bermudagrass cultivar (Cynodon dactylon). The following treatments were tested: Control - no fertilization; LPS30 - $30 \mathrm{~m}^{3} \mathrm{ha}^{-1}$ of LPS; LPS60 - $60 \mathrm{~m}^{3} \mathrm{ha}^{-1}$ of LPS; LPS90 $90 \mathrm{~m}^{3} \mathrm{ha}^{-1}$ of LPS, and FertMin - inorganic mineral fertilization. Treatment FertMin-inorganic mineral fertilization was applied in January 2015 at a rate of $200 \mathrm{~kg} \mathrm{~N}$ in the form of urea, $70 \mathrm{~kg} \mathrm{P}_{2} \mathrm{O}_{5}$ as single superphosphate, and $400 \mathrm{~kg} \mathrm{~K}_{2} \mathrm{O}$ as potassium chloride, all on a per hectare basis. The applications of the treatments in the experimental area occurred monthly between January and June 2015. However, the application of LPS was done on March 20, 2015 and June 23, 2015, always at the end of the afternoon, and the nutrient concentrations of the LPS applied on these dates are shown in Table 1.

\section{Sample collection}

Sample collection was conducted using in situ closed-cover static chambers (Fig 3) based on methodology adapted from the literature (Nogueira et al., 2015).

The samples were collected during the morning between 88 10 a.m. (GMT-4) a period considered representative of average daily GHG flux (Zuchello, 2010). Immediately after coupling the chamber on the metallic base, a sample of atmospheric air was collected using a plastic syringe with a volume of $20 \mathrm{~cm}^{3}$. Thirty minutes after coupling of chamber, the first air sample was collected from its interior, followed by another sample at 60 minutes, for a total of three samples taken at 0,30 , and 60 minutes. To facilitate sample collection, the chamber had a connecting port on its top that is regulated using a three-way plastic valve. The syringe was connected to this valve by another three-way plastic valve, which ensured proper sealing after sample collection (Rodrigues and Mello, 2012). After each collection, the samples were transferred to flasks that had their air content removed by vacuum. Additionally, air and soil temperatures were measured during sampling.

Intensive sample collection campaigns (IC) were done in two distinct periods, with the first IC done between March 18 and April 20, 2015, and the second IC between June 22 and July 23,2015 . The IC were conducted during the three days that preceded the application of the LPS, and also on the day of the application and the period afterward, with the goal of accompanying the pattern of GHG flux resulting from the fertilization treatments.

\section{Laboratory analyses}

The determination of gas concentrations was done at Embrapa Agrossilvipastoril using a gas chromatograph (model Shimadzu GC-2014) with FID and ECD detectors and an automatic injector. The calibration curves were determined using three gas standards for $\mathrm{CO}_{2}, \mathrm{CH}_{4}$ and $\mathrm{N}_{2} \mathrm{O}$ (White Martins). These standards were: 308,$700 ; 714,600$ and $5097,000 \mathrm{micromol} / \mathrm{mol}$, for $\mathrm{CO}_{2} ; 1,402 ; 9,722$ and $100,300 \mathrm{micromol} / \mathrm{mol}$, for $\mathrm{CH}_{4}$; and 360,$000 ; 832,000$ and $2080,000 \mathrm{nanomol} / \mathrm{mol}$, for $\mathrm{N}_{2} \mathrm{O}$. The time for which the samples were analyzed was 8 minutes.

\section{Statistical analysis}

Average and accumulated flux data for $\mathrm{CO}_{2}, \mathrm{CH}_{4}$ and $\mathrm{N}_{2} \mathrm{O}$ were processed for descriptive analysis and analyzed for normality (Shapiro-Wilk), homogeneity of variances (Levene), analysis of variance (ANOVA), and treatment means were compared using the Tukey's test $(p<0.05)$. When necessary, the data were log transformed in order to homogenize the variances and normalize the frequency distribution. These results were transformed using the inverse operation to present the data in their original units.

\section{Conclusion}

The influence of fertilization with LPS increased the fluxes of $\mathrm{CO}_{2}$ and $\mathrm{CH}_{4}$ from the first hours after its application. During the period with greater precipitation, $\mathrm{CO} 2$ emissions were higher than in the dry season. However, the application of LPS in Tifton-85 pasture during rainy periods did not have high potential for emission of $\mathrm{CO}_{2}$, in contrast to this application during the dry season. The soil fertilized with LPS is occasionally a source of $\mathrm{CH}_{4}$ during periods with greater rainfall. Fertilization with LPS increases the emission of $\mathrm{N}_{2} \mathrm{O}$, and this varies as a function of the volume of LPS applied and the experimental conditions. The application of LPS in Tifton-85 pasture has a high potential for $\mathrm{N}_{2} \mathrm{O}$ emission during the rainy season, but the magnitude is similar to that resulting from inorganic mineral fertilization. The emission of GHGs by the LPS treatments in this study were similar to 
those observed in the area that received inorganic mineral fertilizer.

\section{Acknowledgments}

This study was financed in part by the Coordenação de Aperfeiçoamento de Pessoal de Nível Superior - Brasil (CAPES) - Finance Code 001 and BRF S.A.

\section{References}

Aita C, Gonzatto R, Miola ECC, Santos DB, Rochette P, Angers DA, Chantigny MH, Pujol SB, Giacomini DA, Giacomini SJ (2014) Injection of dicyandiamide-treated pig slurry reduced ammonia volatilization without enhancing soil nitrous oxide emissions from no-till corn in southern brazil. J Environ Qual. 43(3): 789-800.

Aita C, Port O, Giacomini SJ (2006) Dinâmica do nitrogênio no solo e produção de fitomassa por plantas de cobertura no outono/inverno com o uso de dejetos de suínos. Rev Bras Cienc Solo. 30(5): 901-910.

Aita C, Schirmann J, Pujol SB, Giacomini SJ, Rochette P, Angers DA, Chantigny $\mathrm{MH}$, Gonzatto R, Giacomini DA, Doneda A (2015) Reducing nitrous oxide emissions from a maize-wheat sequence by decreasing soil nitrate concentration: effects of split application of pig slurry and dicyandiamide. Eur J Soil Sci. 66(2): 359-368.

Arenhardt, MH (2016) Emissões de gases de efeito estufa em resposta ao modo de aplicação de dejetos de suínos e ao uso de inibidor de nitrificação na sucessão trigo/milho em latossolo. Santa Maria: Universidade Federal de Santa Maria, 2016. Dissertation, $77 \mathrm{f}$.

Camargo SC, Mesquita EE, Castagnara DD, Neres MA, Oliveira PSR (2011) Efeito da aplicação de dejetos de suínos na concentração de minerais na parte aérea de capins Tifton 85. Scientia Agrar Par. 10(2): 51-62.

Carvalho NL, Hentz, P. Impactos ambientais da fertilização orgânica em sistemas agropecuários na região sulbrasileira. REGET. 18(1): 340-352.

Carvalho JLN, Avanzi JC, Silva MLN, Mello CRD, Cerri CEP (2010) Potencial de sequestro de carbono em diferentes biomas do Brasil. Rev Bras Cienc Solo. 341(2): 277-290.

Ceretta CA, Basso CJ, Pavinato PS, Trentin EE, Girotto E (2005) Produtividade de grãos de milho, produção de matéria seca e acúmulo de nitrogênio, fósforo e potássio na rotação aveia preta/milho/nabo forrageiro com aplicação de dejeto líquido de suínos. Cienc Rural. 35(6): 1287-1295.

Damasceno F (2010) Injeção de dejetos líquidos de suínos no solo e inibidor de nitrificação como estratégias para reduzir as emissões de amônia e óxido nitroso. Santa Maria: Universidade Federal de Santa Maria, 2010. Dissertation, $93 \mathrm{f}$.

Denega GL (2009) Emissão de óxido nitroso e dióxido de carbono após aplicação de dejetos de suínos e bovinos em um argissolo. Santa Maria: Universidade Federal de Santa Maria, 2010. Dissertation, $122 \mathrm{f}$.

Drumond LCD, Zanini JR, Aguiar APA, Rodrigues GP, Fernandes ALT (2006) Produção de matéria seca em pastagem de Tifton 85 irrigada, com diferentes doses de dejeto líquido de suíno. Eng Agric. 26(2): 426-433.

Friederichs A, Borges Júnior WS, Roters DF, Mafra AL (2019) Emissão de $\mathrm{CO}_{2}$ do solo pela aplicação de fertilizantes orgânicos e minerais em ambiente controlado. Rev Agropec Catarin. 32(2): 86-91.

Gerber PJ, Steinfeld H, Henderson B, Mottet A, Opio C, Dijkman J, Falcucci A, Tempio G (2013) Tackling climate change through livestock e a global assessment of emissions and mitigation opportunities. Food and Agriculture Organization of the United Nations (FAO), Rome.

Giacomini S, Recous S, Mary B, Aita C (2007) Simulating the effects of $\mathrm{N}$ availability, straw particle size and location in soil on C and N mineralization. Plant and Soil. 301(1): 289301.

Giacomini SJ, Aita C (2008) Emissão de dióxido de carbono após aplicação de dejetos líquidos e cama sobreposta de suínos. Pesqui Agropecu Bras. 43(1): 107-114.

Giacomini SJ, Jantalia CP, Aita C, Urquiaga S (2006) Emissão de óxido nitroso com a aplicação de dejetos líquidos de suínos em solo sob plantio direto. Pesqui Agropecu Bras. 41(11): 1653-1661.

Grave R, Nicoloso RS, Cassol PC, Aita C, Corrêa JC, Costa MD, Fritz DD (2014) Short-term carbon dioxide emission under contrasting soil disturbance levels and organic amendments. Soil Tillage Res. 146: 184-192.

IBGE - Instituto Brasileiro de Geografia e Estatística. Pesquisa da Pecuária Municipal - PPM, 2018. <https://www.ibge.gov.br/estatisticas/economicas/agricul tura-e-pecuaria/9107-producao-da-pecuariamunicipal.html?=\&t=resultados $>25$ Set.

Jantalia CP, Santos HP, Urquiaga S, Boddey RM, Alves BJR (2008) Fluxes of nitrous oxide from soil under different crop rotations and tillage systems in the south of Brazil. Nutr Cycling Agroecosyst. 82(2): 161-173.

Jarecki MK, Parkin TB, Chan AS, Hatfield JL, Jones R (2008) Greenhouse gas emissions from two soils receiving nitrogen fertilizer and swine manure slurry. J Environ Qual. 37(4): 1432-1438.

Karstensen J, Peters GP, Andrew RM (2013) Attribution of $\mathrm{CO}_{2}$ emissions from Brazilian deforestation to consumers between 1990 and 2010. Environ Res Lett. 8: 1-7.

Kebreab E, Liedke A, Caro D, Diemling S, Binder M, Finkbeiner M (2016) Environmental impact of using specialty feed ingredients in swine and poultry production: a life cycle assessment. J Animal Sci. 94: 2664-2681.

Le Mer J, Roger P (2001) Production, oxidation, emission and consumption of methane by soils: A review. Eur J Soil Biol. 37(1): 25-50.

IPCC - Intergovernmental Panel on Climate Change (2007) Climate change 2007: The Physical Science Basis. contribution of working group I to the fourth assessment report of the IPCC, (eds. Solomon S, Qin D, Manning M, Chen $Z$, Marquis $M$, Averyt KB, Tignor $M$, Miller $H L$ ). Cambridge University Press, Cambridge.

Luo Y, Zhou X (2006a) Processes of $\mathrm{CO}_{2}$ production in soil. In: Luo $Y$, Zhou $X$ (eds) soil respiration and the environment, Academic Press, Elsevier, San Diego, 35.

Luo Y, Zhou X (2006b) Controlling factors. In: Luo Y, Zhou X (eds) soil respiration and the environment, Academic Press, Elsevier, San Diego, 79.

Medeiros LT, Rezende AV, Vieira PF, Neto FRC, Valeriano AR, Casali AO, Gastaldello Junior AL (2007) Produção e qualidade da forragem de capim-marandu fertiirrigada com dejetos líquidos de suínos. Rev Bras Zootec. 36(2): 309-318. 
MAPA - Ministério da Agricultura Pecuária e Abastecimento (2019). Projeções do Agronegócio: Brasil 2018/19 a 2028/29 projeções de longo prazo. Brasília, 126 p.

Nogueira AKS, Rodrigues RAR, Castro BS, Nogueira TF, Silva JJN, Behling M, Mombach M, Armacolo N, Silveira JG (2015) Emissões de óxido nitroso e metano do solo em áreas de recuperação de pastagens na amazônia matogrossense. Quim Nova. 38(7): 937-943.

Oliveira PAV (2004) Tecnologias para o manejo de resíduos na produção de suínos: manual de boas práticas. Embrapa Suínos e Aves, 109 p.

Pelster DE, Chantigny MH, Rochette P, Angers DA, Rieux C, Vanasse A (2012) Nitrous oxide emissions respond differently to mineral and organic nitrogen sources in contrasting soil types. J Environ Qual. 41(2): 427-435.

Piva JT, Dieckow J, Bayer C, Zanatta JA, Moraes A, Tomazi M, Pauletti V, Barth G, Piccolo MC (2013) Soil gaseous $\mathrm{N}_{2} \mathrm{O}$ and $\mathrm{CH}_{4}$ emissions and carbon pool due to integrated croplivestock in a subtropical Ferralsol. Agric Ecosyst Environ. 190: 87-93

Rochette $\mathrm{P}$, Angers DA, Chantigny $\mathrm{MH}$, MacDonald JD, Gasser MO, Bertrand N (2008) Reducing ammonia volatilization in a no-till soil by incorporating urea and pig slurry in shallow bands. Nutri Cycling Agroecosyst. 84(1): 71-80.

Rodrigues RAR, Mello, WZD (2012) Fluxos de óxido nitroso em solos com cobertura de floresta ombrófila densa montana na Serra dos Órgãos, Rio de Janeiro. Quim Nova. 35(8) 1549-1553

Saggar S, Tate KR, Giltrap D, Singh JS (2008) Soil-atmosphere exchange of nitrous oxide and methane in New Zealand terrestrial ecosystems and their mitigation options: A review. Plant Soil. 309(1): 25-42.

Scherer EE, Baldissera IT, Miranda M (2012) Produção e qualidade de forragem e atributos do solo influenciados por adubação orgânica e nitrogenada. Epagri, 52 p.

Seganfredo MA (2000) A questão ambiental na utilização de dejetos de suínos como fertilizante do solo. Embrapa Suínos e Aves, 35 p.

Seidel EP, Gonçalves Junior AC, Vanin JP, Strey L, Schwantes D, Nacke H (2010) Aplicação de dejetos de suínos na cultura do milho cultivado em sistema de plantio direto. Acta Sci Technol. 32(2): 113-117.
Sherlock R, Sommer SG, Khan RZ, Wood CW, Guertal EA, Freney JR, Dawson CO, Cameron KC (2002) Ammonia, Methane, and Nitrous Oxide emission from pig slurry applied to a pasture in New Zealand. J Environ Qual. 31(5): 1491-1501.

Silva ADA, Lana ÂMQ, Lana RMQ, Costa AMD (2015) Fertilização com dejetos suínos: influência nas características bromatológicas da Brachiaria decumbens e alterações no solo. Eng Agric. 35(2): 254-265.

Smith E, Gordon R, Bourque C, Campbell A, Génermont S, Rochette P, Mkhabela M (2009) Simulated management effects on ammonia emissions from field applied manure. J Environ Manage. 90(8): 2531-2536.

Suwanwaree P, Robertson GP (2005) Methane oxidation in forest, successional, and no-till agricultural ecosystems. Soil Sci Soc Am J. 69(6): 1722-1729.

Thompson RB, Meisinger JJ (2002) Management factors affecting ammonia volatilization from land-applied cattle slurry in the Mid-Atlantic USA. J environ qual. 31(4): 13291338.

Veiga $M D$, Pandolfo $C M$, Balbinot Junior $A A$, Spagnollo $E$ (2012) Chemical attributes of a hapludox soil after nine years of pig slurry application. Pesq Agropec Bras. 47(12): 1766-1773.

Webb J, Pain B, Bittman S, Morgan J (2010) The impacts of manure application methods on emissions of ammonia, nitrous oxide and on crop response - A review. Agr Ecosyst Environ. 137(1): 39-46.

Zaman M, Blennerhassett J (2010) Effects of the different rates of urease and nitrification inhibitors on gaseous emissions of ammonia and nitrous oxide, nitrate leaching and pasture production from urine patches in an intensive grazed pasture system. Agr Ecosyst Environ. 136(3):236246.

Zanatta JA, Bayer C, Vieira FCB, Gomes J, Tomazi M (2010) Nitrous oxide and methane fluxes in south Brazilian gleysol as affected by nitrogen fertilizers. Rev Bras Cienc Solo. 34(5): 1653-1665.

Zuchello $F$ (2010) Emissões de óxido nitroso $\left(\mathrm{N}_{2} \mathrm{O}\right)$ de cambissolo cultivado com cana-de-açúcar em Campos dos Goytacazes: impacto de adubações com vinhaça e uréia. Seropédica: Universidade Federal Rural do Rio de Janeiro, 2010. Dissertation, $45 \mathrm{f}$ 